\title{
PELATIHAN EFIKASI DIRI ISLAMI UNTUK MENURUNKAN KECEMASAN \\ BERBICARA DI DEPAN UMUM PADA SANTRI
}

\section{ISLAMIC SELF EFFICACY TRAINING TO REDUCE ANXIETY OF PUBLIC SPEAKING FOR ISLAMIC BOARDING SCHOOL STUDENT}

\author{
Faiz Alfi Rachmawati \\ Khoiruddin Bashori \\ Elli Nur Hayati \\ Program Studi Psikologi Profesi, Universitas Ahmad Dahlan, Yogyakarta \\ Email: fa.rachmawati@gmail.com
}

\begin{abstract}
This study was able to find out whether Islamic self-efficacy training can reduce the anxiety of public speaking for the student of Islamic boarding school. The method used in this research was experimental method with randomized pretest-posttest with control group. Subjects in this study were male and female of Islamic boarding school student with range of age 13 to 16 years old which contained 18 subjects with an anxiety score of public speaking in high to medium and divided into two groups, 9 subjects for experimental group and 9 subjects for control group. The experimental group was given self-efficacy training, while the control group was not treated. The scale used to measure anxiety levels in public speaking was public speaking anxiety scale constructed by researcher based on the theory of Rogers (2003). The results were obtained by Mann-Whitney statistic test, the difference of score during pretest-posttest of experimental group with control group showing $Z$ value equal to $-2,790$ with $p=0,005<0,05$. These results indicate significant differences between experimental and control groups. Islamic Self-efficacy training in this study provides positive change and reduces the anxiety of public speaking for Islamic boarding school student, motivate them to improve their positive self by maximizing their excess, and emerge positive emotion to relieve irrational thinking.
\end{abstract}

Key words: Islamic self-efficacy training, public speaking, anxiety, Islamic boarding school student

\begin{abstract}
ABSTRAK
Penelitian ini bertujuan untuk mengetahui apakah pelatihan efikasi diri Islami dapat menurunkan kecemasan berbicara di depan umum pad asantri. Metode yang digunakan dalam penelitian ini adalah metode eksperimen dengan desain ekperimen randomized pretest-posttest with control group. Subjek dalam penelitian ini adalah santri laki-laki dan perempuan berusia 13-16 di sebuah pondok yang berjumlah 18 orang dengan skor kecemasan berbicara di depan umum tinggi hingga sedang dan terbagi menjadi dua kelompok yaitu 9 orang kelompok eksperimen dan 9 orang kelompok kontrol. Kelompok eksperimen diberikan perlakuan berupa pelatihan efikasi diri, sedangkan kelompok kontrol tidak mendapat perlakuan. Skala yang digunakan untuk mengukur tingkat kecemasan berbicara di depan umum adalah skala kecemasan berbicara di depan umum yang disusun peneliti dengan mengacu pada aspek-aspek kecemasan berbicara di depan umum dari pendapat Rogers (2003). Hasil penelitian diperoleh dengan uji statistik Mann-Whitney, selisih skor saat prates-pascates kelompok eksperimen dengan kelompok kontrol yang menunjukkan nilai Z sebesar -2,790dengan $\mathrm{p}=0,005<0,05$. Hasil tersebut menunjukkan bahwa ada perbedaan skor yang signifikan antara kelompok eksperimen dan kelompok kontrol. Pelatihan efikasi diri islami dalam penelitian ini memberikan perubahan positif yakni menurunkan kecemasan berbicara di depan umum pada santri, memberikan motivasi untuk melakukan perubahan diri yang positif dengan memaksimalkan kelebihan yang dimiliki dan memotivasi munculnya emosi positifsehingga menghilangkan pikiran irasional.
\end{abstract}

Kata kunci: pelatihan efikasi diri, kecemasan berbicara di depan umum, santri 
Para peneliti dari University of Cambridge melakukan identifikasi dan mendapati sebanyak empat dari setiap 100 orang mengalami kecemasan. Perempuan memperlihatkan angka lebih tinggi dibandingkan dengan lelaki (Oana, 2016). Penelitian yang dilakukan oleh Rahayu, Ardani dan Sulistyaningsih (2004) pada mahasiswa Akta IV UIN Malang menghasilkan data 45,56 \% mahasiswa mempunyai kecemasan tinggi, 35,27\% mahasiswa mempunyai kecemasan sedang, dan 20,23\% mahasiswa memiliki kecemasan rendah dalam berbicara di depan umum. Menurut Durand dan Barlow (2006), gangguan kecemasan seringkali terwujud sebagai ketakutan dan kekhawatiran yang berlebihan serta kencenderungan untuk menghindari kondisi tekanan berat termasuk pertemuan sosial adalah sebagian dari gangguan kesehatan mental yang paling umum di dunia barat.

Pada manusia kecemasan bisa jadi berupa perasaan gelisah yang bersifat subjektif, sejumlah perilaku (tampak gelisah, khawatir dan resah), atau respon fisiologis yang bersumber di otak dan tercermin dalam bentuk denyut jantung yang meningkat dan otot yang menegang. Tipe fobia tampil yang paling sering dijumpai, yang dialami oleh sebagian besar orang adalah ketakutan untuk berbicara di depan umum (Durand \& Barlow, 2006). Setiap orang mempunyai reaksi yang berbeda terhadap cemas tergantung pada kondisi masing-masing individu. Beberapa simptom yang muncul tidaklah sama antar individu. Ada beberapa simptom yang tidak berpengaruh berat pada beberapa individu, sedangkan untuk individu lainnya simptom tersebut mengganggu (DSM IV, 2000).

Komunikasi melalui public speaking atau berbicara di depan umum adalah sebuah metode berkomunikasi baik secara perorangan maupun dengan sekelompok orang. Adapun yang menjadi fungsi dari berbicara di depan umum adalah untuk menyampaikan informasi, meyakinkan orang lain dan bersifat mengajak. Namun fungsi tersebut mengalami hambatan bilamana individu mengalami kecemasan berbicara di depan umum. Kecemasan berbicara di depan umum dikategorikan sebagai kecemasan sosial atau fobia sosial dalam DSM-IV TR (Haryanthi \& Tresniasari, 2012).

Penelitian yang dilakukan Gaiban dan Elmenfi (2014) menunjukkan bahwa responden yang mengalami kecemasan berbicara di depan umum mengalami perasaan takut, bingung, gemetar, tegang, badan kaku, jantung berdetak kencang, gugup, membuat kesalahan saat menyampaikan materi. Para responden yang belajar dengan bahasa Inggris ini merasa kecemasan berbicara yang dialaminya membuatnya tidak mampu berbicara bahasa Inggris dengan baik, padahal mereka menguasainya. Kondisi ini membuat 
mereka cemas karena merasa kurang mampu mengucapkan dan sering merasa takut dalam berbicara di depan umum.

Ustad dan ustadzah dalam wawancara mengatakan kemampuan berbicara merupakan bagian yang sangat penting dalam kehidupan sehari hari di pondok pesantren. Para santri yang hidup di pondok pesantren juga perlu memiliki kemampuan berbicara dengan baik untuk berinteraksi dengan ustadz, ustadzah dan santri lainnya. Para santri sebagai kader dakwah diharapkan mampu untuk memberikan ide serta menyampaikan dengan baik ilmu yang didapatkannya di pondok pesantren. Oleh karena itu, para santri diharapkan dapat mengungkapkan ide dan menyampaikannya di masyarakat, untuk itu dibutuhkan kemampuan untuk berbicara di depan umum sejak menuntut ilmu di pondok pesantren.

Beberapa santri mengungkapkan dalam wawancara, bahwa para santri mengalami kecemasan berbicara. Kecemasan dapat terjadi dalam berbagai situasi, salah satunya kecemasan berbicara di depan umum. Santri merasa tidak nyaman dan tidak tenang. Santri merasakan gejala fisik seperti jantung berdebar, gugup, gemetar dan nafas tidak teratur. Sedangkan gejala psikis yang dirasakan santri meliputi perasaan takut, tegang dan sulit konsentrasi saat mengalami kecemasan berbicara di depan umum.
Penelitian Warren (2011) menemukan bahwa efikasi diri berpengaruh untuk mengurangi kecemasan berbicara di depan umum. Efikasi diri memberikan motivasi sehingga para siswa merasa percaya diri berbicara di depan umum. Kondisi tersebut menyebabkan para siswa mampu menguasai orang-orang yang menjadi audiens saat berbicara di depan umum.

Dari kondisi tersebut, maka dibutuhkan penanganan bagi para santri yang memiliki kecemasan berbicara di depan umum. Perlu adanya cara untuk mengatasi dampak akibat kecemasan salah satunya melalui pelatihan efikasi diri. Berdasarkan penelitian Riani dan Rozali (2014) diketahui bahwa mahasiswa dengan self efficacy rendah cenderung tidak memiliki keyakinan akan kemampuannya dalam menghadapi kesulitan di tugas presentasinya. Mahasiswa mudah menyerah tanpa melakukan usaha terlebih dahulu ketika dihadapkan pada tugas presentasi, pesimis bahwa dirinya tidak mampu melakukan tugas presentasi, takut menghadapi resiko ketika presentasi berlangsung, dan merasa tidak mampu melakukan tugas presentasi seperti temanteman lainnya. Hal inilah yang membuat mahasiswa dengan self efficacy rendah menjadi takut dan cemas setiap menghadapi tugas presentasi.

Berdasarkan uraian di atas, hipotesis yang diajukan dalam penelitian ini adalah 
ada pengaruh pelatihan efikasi diri dalam menurunkan kecemasan berbicara di depan umum pada santri.

\section{METODE PENELITIAN}

\section{Rancangan Penelitian}

Penelitian ini merupakan penelitian kuantitatif dengan menggunakan metode penelitian eksperimen. Menurut Latipun (2015), penelitian eksperimen adalah penelitian yang dilakukan dengan melakukan manipulasi yang bertujuan untuk mengetahui akibat manipulasi terhadap perilaku individu yang diamati.

Desain penelitian eksperimen yang digunakan dalam penelitian ini adalah desain eksperimen ulang random (randomized pretest-posttest with control group design). Desain eksperimen ini melakukan prates sebelum perlakuan diberikan dan pascates sesudahnya, sekaligus ada perlakuan. Kelompok kontrol dalam penelitian ini tidak diberikan perlakuan yang sama dengan kelompok eksperimen. Keseluruhan pelaksanan prates dan pascates menggunakan skala kecemasan berbicara di depan umum sebagai hasil evaluasi pelaksanaan penelitian.

\section{Partisipan}

Pengambilan subjek dalam penelitian ini menggunakan teknik purposive sampling, yaitu salah satu teknik pengambilan sampel yang berdasarkan atas suatu pertimbangan tertentu seperti sifat-sifat populasi ataupun ciri-ciri yang sudah diketahui sebelumnya (Notoatmodjo, 2010).

Subjek yang terlibat dalam penelitian ini adalah santri di pondok pesantren berjumlah 18 orang. Sebelum penentuan 18 subjek di atas, dilakukan screening (seleksi), dan akhirnya 18 orang memenuhi persyaratan sebagai peserta. Bagi subjek yang mendapatkan skor sedang dan tinggi terlibat dalam penelitian dan dijadikan sebagai kelompok eksperimen yang langsung diberikan pelatihan efikasi diri. Kriteria subjek penelitian yang termasuk dalam penelitian ini adalah (a) Santri laki-laki atau perempuan yang tinggal di pondok pesantren. (b) Memiliki skor kecemasan berbicara di depan umum yang sedang hingga tinggi. (c) Belum pernah mengikuti pelatihan efikasi diri.

Total subjek dalam penelitian ini berjumlah 18 santri yang terbagi menjadi 2 kelompok, yaitu 9 santri kelompok eksperimen dan 9 santri kelompok kontrol. Kedua kelompok tersebut diberikan skala kecemasan berbicara di depan umum.

\section{Metode Pengumpulan Data}

Pengumpulan data yang digunakan dalam penelitian ini menggunakan skala. Adapun skala yang digunakan dalam penelitian ini adalah skala kecemasan 
berbicara di depan umum yang disusun oleh peneliti berdasarkan aspek-aspek kecemasan berbicara di depan umum dari Roger (2003), yaitu respon fisik, respon kognitif, dan respon emosional.

Pada penelitian ini peneliti membagikan skala kepada subjek secara langsung untuk diberikan respon sesuai pernyataan yang tertera di skala dan kondisi subjek. Berdasarkan skala ini peneliti mengumpulkan data dari variabel yang diteliti dan mengolah data dari hasil skor jawaban yang telah diberikan oleh subjek.

Skala kecemasan berbicara di depan umum terdiri atas tiga aspek, yaitu respon fisik terdiri atas 11 pertanyaan, respon kognitif terdiri atas 8 pertanyaan dan respon emosional terdiri atas 8 pertanyaan. Total jumlah aitem dalam skala ini berjumlah 27. Skala kecemasan berbicara di depan umum memiliki koefisien alpha 0.911 .

\section{Prosedur Intervensi}

Penyusunan modul penelitian oleh peneliti dimaksudkan sebagai panduan dalam pelaksanan pelatihan. Modul disusun berdasarkan dari teori dan aspek efikasi diri (Bandura, 1997), yang disesuaikan dengan tujuan yang ingin dicapai. Hal yang dilakukan sebelum pembuatan modul adalah pembuatan kisi-kisi modul. Adapun kisi-kisi atau blue print modul dapat dilihat pada tabel berikut ini:

Tabel 1. Blue print Modul Pelatihan Efikasi diri

\begin{tabular}{|c|c|c|c|c|}
\hline No & Aspek-aspek & Ciri-ciri Perilaku & Sesi & Waktu \\
\hline 1 & $\begin{array}{l}\text { Tingkatan kesulitan } \\
\text { tugas } \\
\text { (sesi meningkatkan } \\
\text { daya juang) }\end{array}$ & $\begin{array}{l}\text { Memahami tentang pola } \\
\text { pikir yang keliru sehingga } \\
\text { muncul usaha untuk } \\
\text { mengatasi kesulitan dalam } \\
\text { menghadapi situasi yang } \\
\text { tidak menyenangkan }\end{array}$ & $\begin{array}{l}\text { Psiko edukasi efikasi diri } \\
\text { dan menggali potensi diri }\end{array}$ & 70 menit \\
\hline 2 & $\begin{array}{l}\text { Keadaan umum suatu } \\
\text { tugas } \\
\text { (Sesi meminimalisir } \\
\text { sumber kecemasan } \\
\text { dengan membuat } \\
\text { strategi) }\end{array}$ & $\begin{array}{l}\text { Mampu meyakinikan dan } \\
\text { mendorong dirinya untuk } \\
\text { menghadapi situasi sesuai } \\
\text { dengan kemampuan }\end{array}$ & $\begin{array}{l}\text { Meditasi zikir, meditasi } \\
\text { syukur }\end{array}$ & 70 menit \\
\hline 3 & $\begin{array}{l}\text { Keyakinan seseorang } \\
\text { dalam menyelesaikan } \\
\text { tugas } \\
\text { (sesi evaluasi diri) }\end{array}$ & $\begin{array}{l}\text { Membentuk keyakinan } \\
\text { yang kuat terhadap } \\
\text { kemampuan yang dimiliki }\end{array}$ & $\begin{array}{l}\text { Afirmasi positif, membuat } \\
\text { penilaian positif dan } \\
\text { membentuk percaya diri }\end{array}$ & 85 menit \\
\hline
\end{tabular}

\section{Analisis Data}

Metode analisis data yang digunakan adalah metode kuantitatif. Metode kuantitatif yang dilakukan adalah pengujian data hasil dari skala kecemasan berbicara di depan umum dengan menggunakan uji Mann-Whitney $U$ dengan menggunakan bantuan program SPSS 21.0 for windows. 
Pelatihan Efikasi Diri Islami untuk Menurunkan Kecemasan Berbicara di Depan Umum ...

\section{HASIL PENELITIAN}

\section{Deskripsi Data Penelitian}

Hasil penelitian menunjukkan mean prates dengan nilai 76,67 . Saat pascates mean turun menjadi 67,56, sedangkan saat follow up mean turun walaupun sedikit menjadi 67,44. Nilai SD berturut-turut, prates 9,971, pascates 10,013 dan tindak lanjut 9,568. Pada penelitian nilai minimal prates 64 dan nilai maksimalnya 108 . Nilai minimal pascates turun menjadi 33 dan maksimal 81.Sedangkan nilai minimal follow up 52 dan maksimal 99. Hasil tersebut dapat dilihat dari tabel di bawah ini.

Tabel 2. Mean, SD, Min dan Max Prates, pascates dan tindak lanjut

\begin{tabular}{ccccc}
\hline & Mean & Std. Deviation & Minimum & Maximum \\
\hline Prates & 76.67 & 9.971 & 64 & 108 \\
Pascates & 67.56 & 10.013 & 33 & 81 \\
Followup & 67.44 & 9.568 & 52 & 99 \\
\hline
\end{tabular}

\section{Hasil Uji Asumsi}

Uji Normalitas. Hasil uji normalitas antara kelompok eksperimen dan kelompok kontrol dengan metode kolmogorov smirnov yaitu prates perolehan nilai $\mathrm{z}$ sebesar 0,717 dengan nilai signifikansi 0,683 (>0,05). Karenanya, dapat disimpulkan bahwa data berdisitribusi normal. Sedangkan pascates perolehan nilai $\mathrm{z}$
1,085 dengan nilai signifikansi 0,190 $(<0,05)$. Karenanya, dapat disim-pulkan bahwa data berdisitribusi normal dan follow up perolehan nilai z 0,874 nilai signifikansi $0,430(<0,05)$ maka dapat disimpulkan bahwa data berdis-tribusi normal. Hasil tersebut dapat dilihat dari tabel di bawah ini.

Tabel 3. Uji Normalitas Kelompok Eksperimen dan Kelompok Kontrol

\begin{tabular}{cccc}
\hline & K-S-Z & $\begin{array}{c}\text { Asymp. } \\
\text { Sig. 2 tailed }\end{array}$ & Deskripsi \\
\hline Prates & 0,717 & 0,683 & Terdistribusi normal \\
Pascates & 1,085 & 0,190 & Terdistribusi normal \\
Tindaklanjut & 0,874 & 0,430 & Terdistribusi normal \\
\hline
\end{tabular}

Uji Homogenitas. Hasil uji homogenitas antara kelompok eksperimen dan kelompok kontrol dengan metode levene statistic yaitu data homogeny pada score prates, pascates dan tindak lanjut yang ditunjukkan dengan nilai $F$ 2,959 taraf signifikansi 0,105 (>0,05), sedangkan pascates nilai $\mathrm{F} \quad 0,904$ pada taraf signifikansi 0,356 $(>0,05)$ dan pada tindak lanjut nilai $\mathrm{F} 0,264$ taraf signifikansi 0,614 (>0,05). Hasil tersebut dapat dilihat dari tabel di bawah ini. 
Tabel 4. Uji Homogenitas Antara Kelompok Eksperimen dan Kelompok Kontrol

\begin{tabular}{cccc}
\hline & F & Sig. & Deskripsi \\
\hline Prates & 2,959 & 0,105 & Homogen \\
Pascates & 0,904 & 0,356 & Homogen \\
Tindaklanjut & 0,264 & 0,614 & Homogen \\
\hline
\end{tabular}

\section{Hasil Uji Hipotesis}

Hasil analisis Mann Whitney $U$ Test diperoleh hasil uji perbedaan antar kelompok eksperimen dan kontrol diperoleh hasil bahwa ada perbedaan yang signifikan pada prates ke pascates yang ditunjukkan dari nilai Z $-2,790$ dengan nilai signifikansi $0,005(<0,05)$ dan gain score pascates-tindaklanjut yang ditunjukkan dari nilai Z -2,168 dengan nilai signifikansi $0,030(>0,05)$. Perbedaan tidak terjadi pada prates ke tindak lanjut yang ditunjukkan dari nilai Z -0,886 dengan nilai signifikansi 0,376 $(>0,05)$. Hasil tersebut dapat dilihat dari tabel di bawah ini.

Tabel 5. Hasil Uji Beda Kelompok Eksperimen dan Kelompok Kontrol

\begin{tabular}{lccc}
\hline & Z & Asymp.Sig. 2 tailed & Deskripsi \\
\hline Pre-post & $-2,790$ & 0,005 & Ada perbedaan yang signifikan \\
Pre-tindaklanjut & $-0,886$ & 0,376 & Tidak ada perbedaan yang signifikan \\
Post- & $-2,168$ & 0,030 & Ada perbedaan yang signifikan \\
tindaklanjut & & & \\
\hline
\end{tabular}

\section{PEMBAHASAN}

Menurut Corey (2009), terbentuknya perilaku disebabkan adanya peran lingkungan dalam bentuk konsekuensikonsekuensi yang mengikuti dari suatu perilaku dan hal itu termasuk dalam teori belajar perilaku operan (operan conditioning theory) dari Skinner. Pada penelitian ini, para santri memiliki pola pikir yang negatif ketika berbicara di depan umum. Para santri menjadi tidak dapat berkonsentrasi, mengalami kebingungan dan tidak tahu apa yang harus dilakukan ketika tiba gilirannya untuk berbicara.
Para santri merasa dirinya terancam dan mempersepsikan kegiatan berbicara di depan umum sebagai masalah besar, sehingga menyebabkan munculnya rasa khawatir, gelisah dan takut. Kondisi ini menyebabkan para santri mengalami rasa cemas untuk berbicara di depan umum.

Saat berada dalam situasi berbicara di depan umum, para santri tidak bisa mengendalikan perilaku motoriknya, sehingga muncul reaksi gemetar dan gugup. Para santri mengalami kecemasan ketika berbicara di depan umum karena tidak terkendalinya manifestasi gejala fisik, proses mental, dan gejala emosi. 
Para santri kurang memiliki keyakinan diri untuk mampu berani berbicara di depan umum sehingga perlu diberikan pelatihan efikasi diri islami untuk mengubah pikiran-pikiran negatifnya sehingga mereka dapat mengendalikan kecemasan berbicara yang dialami. Menurut Bandura (1997), efikasi diri berguna untuk melatih individu bangkit dari perasaan cemas yang menyebabkan keyakinan diri yang rendah.

Keyakinan individu untuk melakukan suatu tindakan mempengaruhi aktivitas serta usaha yang dilakukan individu dalam menghadapi kesulitan penyelesaian tugas. Artinya keyakinan tersebut akan memotivasi individu untuk mencapai hasil yang maksimal. Faktor kognitif mempengaruhi cara individu dalam mempersepsikan keyakinan dirinya tentang mampu atau tidak mampu untuk berperilaku setelah melakukan berbagai usaha dalam mencapai hasil yang positif (Feist \& Feist, 2002). Perubahan pola pikir yang lebih positif akibat pelatihan yang diberikan akan meningkatkan keyakinan diri (self efficacy) individu. Dengan meningkatnya efikasi diri, maka kecemasan berbicara di depan umum akan dapat lebih dikendalikan.

Menurut Bandura (1997), individu yang memiliki self efficacy yang rendah tidak berfikir tentang bagaimana cara yang baik dalam menghadapi tugas-tugas yang sulit. Saat menghadapi tugas yang sulit, individu tersebut mengurangi usahausahanya dan cepat menyerah. Individu tersebut juga lamban dalam membenahi ataupun mendapatkan kembali self efficacy mereka ketika menghadapi kegagalan. Feist dan Feist (2002) juga mengemukakan bahwa ketika seseorang mengalami kecemasan yang tinggi maka mereka biasanya memiliki efikasi diri yang rendah. Sementara yang memiliki efikasi diri yang tinggi merasa mampu mengatasi rintangan dan menganggap ancaman sebagai suatu tantangan yang tidak perlu dihindari. Hal itu sesuai dengan hasil penelitian bahwa semakin tinggi efikasi diri seseorang maka tingkat kecemasan berbicara di depan umum semakin rendah, begitupula sebaliknya.

Hasil penelitian menunjukkan bahwa terdapat perbedaan yang signifikan skor kecemasan berbicara di depan umum pada kelompok eksperimen saat prates, pascates dan tindak lanjut. Berdasarkan hasil analisis tersebut maka dapat disimpulkan bahwa pelatihan efikasi diri yang dilakukan dapat menurunkan kecemasan berbicara di depan umum pada santri. Pelatihan efikasi diri memberikan perubahan-perubahan di antaranya santri mempunyai persepsi positif, lebih yakin terhadap kemampuannya, kecemasannya menurun serta termotivasi untuk meningkatkan daya juang. 
Efektifitas pelatihan efikasi diri pada kecemasan berbicara di depan umum pada santri menunjukkan adanya perubahan secara kognitif, afektif dan konatif. Beberapa keterbatasan penelitian ini terletak pada kurangnya komunikasi peneliti dengan pengasuh pondok untuk memberikan kesempatan dan latihan berbicara di depan umum pada santri yang mengalami kecemasan berbicara. Selain itu juga kurangnya pemberian tugas rumah (misalnya buku monitoring harian) secara berkala untuk mengevaluasi dan memantau kemajuan atau peningkatan yang terjadi pada partisipan sekaligus untuk meyakinakan partisipan tentang materi yang disampaikan. Keterbatasan lainnya terletak pada kurangnya waktu untuk dapat sharing kelompok.

Keterbatasan peneilitian berikutnya adalah terkait modul yang kurang dalam alokasi sesi pelatihannya (hanya dilaksanakan satu hari). Ada baiknya pelatihan dilaksanakan beberapa kali pertemuan dalam beberapa hari. Kondisi ini menyebabkan pemahaman materi pelatihan belum bisa diserap secara maksimal oleh santri. Santri juga belum mendapat praktek langsung dalam berbicara di depan umum, sehingga efek pelatihan efikasi dirinya tidak bertahan lama.

\section{SIMPULAN DAN SARAN}

\section{Simpulan}

Hasil penelitian menunjukkan bahwa pelatihan efikasi diri memberikan pengaruh secara efektif pada menurunnya kecemasan berbicara di depan umum pada santri. Berdasarkan analisis kuantitatif menunjukkan hasil ada penurunan skor skala kecemasan berbicara dari prates ke pascates. Akan tetapi, saat tindak lanjut beberapa subjek memiliki skor kecemasan berbicara yang naik. Kondisi ini terjadinya karena kurang gigihnya para subjek untuk berlatih sebanyak dan sesering mungkin untuk berbicara di depan umum.

Secara kualitatif, masing-masing partisipan merasakan adanya manfaat setelah mengikuti pelatihan efikasi diri ini, yaitu merasa lebih tenang, termotivasi untuk percaya diri, belajar memahami kelebihan dan kekurangan yang dimiliki, senantiasa bersyukur dengan segala nikmat kelebihan sekecil apapun yang dimiliki serta berusaha menilai sesuatu secara positif. Keberhasilan dari pelatihan ini didukung oleh beberapa faktor, yaitu modul yang telah direview oleh professional judgement, fasilitator yang berkompeten, motivasi peserta, dan pendekatan atau rapport yang terjalin dengan baik sejak awal screening secara kelompok, pendekatan secara berkelompok mampu memberikan dukungan antar peserta. 


\section{Saran}

Berdasarkan pelaksanaan penelitian dan hasil yang diperoleh, maka peneliti mengajukan saran. Pertama: saran bagi partisipan penelitian. Partisipan yang telah mengikuti penelitian mengenai pelatihan efikasi diri untuk melatih efikasi diri dengan terus berlatih setiap hari. Berlatih memberikan peni-laian positif dan menghilangkan pikiran negatif, berlatih memaksimalkan kemampuan yang dimiliki untuk menurunkan kecemasan berbicara.

Kedua: Saran bagi pengurus pondok. Pihak pengurus pondok diharapkan untuk bisa membantu dalam memotivasi, memberi dukungan dan menjadi pengingat bagi para santri untuk meningkatkan kepercayaan diri dalam berbicara di depan umum. Pihak pengurus juga memberikan kesempatan yang sama bagi para santri untuk mempraktekan kemampuan berbicara

Ketiga: Saran bagi penelitian selanjutnya: (a) Penelitian selanjutnya diharapkan untuk bisa melakukan monitoring harian secara berkala terhadap usaha dalam berbicara di depan umum. (b) Penelitian selanjutnya diharapkan untuk dapat lebih memberikan waktu yang banyak untuk sharing berkelompok antar subjek dengan tujuan antar subjek dapat saling menguatkan, lebih termotivasi untuk meningkatan kepercayaan diri dalam berbicara. (c) Penelitian selan- jutnya untuk melakukan pengontrolan terhadap interaksi kelompok eksperimen dan kontrol dengan memberikan peraturan. Bagi subjek yang dapat melaksanakan peraturan, maka diberikan reward. (d) Penelitian selanjutnya untuk memperbanyak jumlah jam pelatihan dan metode pelatihan yaitu memperbanyak aspek psikomotor ketika praktek berbicara. Selain itu, juga memberikan sesi khusus untuk praktek berbicara di depan umum untuk menghilangkan pola pikir yang keliru dengan berlatih terus-menerus dalam berbicara. Kondisi ini diharapkan dapat meningkatkan keyakinan diri dalam berbicara.

\section{DAFTAR PUSTAKA}

Azwar, S. (2015). Reliabilitas dan validitas (edisi empat). Yogyakarta: Pustaka Pelajar.

Bandura, A. (1997). Self efficacy the exercise of control. New York: W.H Freeman Company.

Baroroh, K. (2006). Pendidikan formal di lingkungan pesantren sebagai upaya meningkatkan kualitas sumber daya manusia. Jurnal pendidikan \& ekonomi, 3 (1), 42-52.

Corey, G. (2009). Konseling dan psikoterapi. Bandung: Refika Aditama.

De Vito, J. A. (1996). Human communication. Jakarta: Profesional Books. 
Durand, V. M., \& Barlow, D. H. (2006). Psikologi abnormal. Yogyakarta: Pustaka Pelajar.

American Psychiatric Association. (2000). Diagnostic and statistical manual of mental disorders (DSM IV-TR). Washington DC: American Psychiatric Association.

Fatma, A \& Ernawati, S. (2012). Pendekatan perilaku kognitif dalam pelatihan ketrampilan mengelola kecemasan berbicara di depan umum. Talenta Psikologi, 1 (1), 3965.

Feist, J \& Feist, G. J. (2002). Theories of personality (5thed). Boston: McGraw Hill.

Gaiban, A. \& Elmenfi, F. (2012).The role of gender in influencing public speaking anxiety. International Journal of Gender and Women's Studies, 12 (2), 105-116.

Harianti. (2014). Hubungan antara self efficacy dengan kecemasan berbicara di depan umum pada mahasiswa. Psikovidya, 18 (1), 8098.

Haryanthi, L. P. S., \& Tresniasari, N. (2012). Efektivitas metode terapi ego state dalam mengatasi kecemasan berbicara di depan publik pada mahasiswa. Insan, 14 (1), 32-40.
Koentjoro \& Mukhlis, H. (2015). Pelatihan kebersyukuran untuk menurunkan kecemasan menghadapi ujian nasional pada siswa sma. Gadjah Mada Journal of Professional Psychology, 1 (3), 203-215.

Latipun. (2015). Psikologi eksperimen (edisi ketiga). Malang: UMM Press.

Musaba, Z. (2012). Terampil berbicara teori dan pedoman. Yogyakarta: Aswaja Pressindo.

Muslimin, K., Maswan dan Lila, A. F. (2013). Mengatasi cemas dalam berkomunikasi di depan publik. Yogyakarta: Lingkar Media.

Nevid, J. S., Rathus, S. A., \& Greene, B. (2005). Psikologi abnormal. Jakarta: Erlangga.

Nooripour, Apsche, Velasco \& Aminizadeh. (2014). Effectiveness of self efficacy group theraphy on problem solving skill and sexual self efficacy in addicted women. Internatioal Journal of Behavior Consultation and Theraphy, 9 (1), 35-38.

Notoatmodjo, S. (2010). Metodologi penelitian kesehatan. Jakarta: Rineka Cipta.

Nurlaila. (2011). Pelatihan efikasi diri untuk menurunkan kecemasan siswa siswi yang akan menghadapi ujian akhir nasional. Guidena, 1 (1), 1-22. 
Oana. (2016, Juni 8). Perempuan lebih beresiko terserang rasa kecemasan. Diunduh 5 April 2017, melalui http://harian.analisadaily.com/news $? \mathrm{r}=242572$.

Osborne, J. W. (2004). Kiat berbicara di depan umum untuk eksekutif. Jakarta: Bumi Aksara.

Papalia, D. E., Old, S. W., \& Feldman, R. D. (2009). Human development: perkembangan manusia. Jakarta: Salemba Medika.

Putra, A.A., Nashori, F. \& Sulistyarini, I. (2012). Terapi kelompok untuk mengurangi kesepian dan menurunkan tekanan darah pada lansia penderita hipertensl. Jurnal Intervensi Psikologi, 4 (1), 1-15.

Rahayu,I. T., Ardani, T. A., \& Sulistyaningsih. (2004). Hubungan pola pikir positif dengan kecemasan berbicara di depan umum. Jurnal Psikologi UNDIP, 1 (2), 131-143.

Rahmawati, F. E., \& Nuryono, W. (2014). Penerapan terapi NLP (neuro lingustic programming) untuk menurunkan kecemasan berbicara di depan umum pada siswa. Jurnal Bimbingan Konseling, 4 (3), 675682.

Riani \& Rozali. (2014). Hubungan antara self efficacy dengan kecemasan saat presentasi pada mahasiswa. Jurnal Psikologi, 12 (1), 1-9.

Rogers, N. (2003). Berani bicara di depan publik. Bandung: Nuansa Cendikia.

Setyonegoro, A. (2013). Hakikat, alasan dan tujuan bicara. Pena, 3 (1), 6780.

Tahmassian, K \& Moghadam, N. (2012). Relationship between self efficacy and symptoms of anxiety, depression, worry and social avoidance in normal sample of students. Iran J psychiatry Behav, 15 (2), 10-20.

Tilfarliglu, F \& Cinkara, E. (2009). Self efficacy in efl : differences among proficiency groups and relationship with success. Nouitas royal, 3 (2), 129-142.

Wahyuni, S. (2014). Hubungan antara kepercayaan diri dengan kecemasan berbicara di depan umum pada mahsiswa. Jurnal Psikologi, 2 (1), 50-64.

Warren, J. (2011). The relationship between service learning and public speaking self efficacy toward engaging today's undergraduates. Disertasi (tidak dipublikasikan). University of Kentucky, Lexington. 


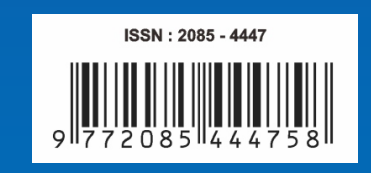

